\title{
The effectiveness of thermotherapy in the elimination of Varroa destructor
}

\author{
Vítězslav Bičík, Jiří Vagera \& Hana Sádovská
}

\begin{abstract}
The effectiveness of thermotherapy in the elimination of Varroa destructor. - Acta Mus. Siles. Sci. Natur. 65: 263-269, 2016

Abstract: Linhart's thermosolar hive was tested on its efficiency in suppressing the mite Varroa destructor Anderson \& Trueman 2000 in honey bee colonies. It has been experimentally verified that thermotherapy is highly effective in suppressing Varroa destructor. When the temperature of the brood chamber is allowed to reach and is maintained at $40-47^{\circ} \mathrm{C}\left(104-116,6^{\circ} \mathrm{F}\right)$ over a period of 2.5 hours, mortality of the mites in the sealed brood is virtually absolute, whereas bee brood withstands this temperature unharmed. Since thermotherapy is carried out with an open entrance, it is advisable to repeat the heating treatment cycle in order to achieve a highly effective elimination of the mites throughout the entire bee colony. The second treatment should be conducted after the remaining mites, which were carried by adult bees not present in the hive during the initial thermotherapy, transferred back to the brood. This occurs about $10-12$ days after the first treatment.
\end{abstract}

Key words: Apis mellifera, Apis cerana, Varroa destructor, mortality, thermosolar therapy,

\section{Introduction}

The Varroa mite (Varroa destructor Anderson \& Trueman, 2000) currently presents the dominant challenge in beekeeping, as it is the cause of widespread mortality among honey bee colonies. The original host of the Varroa mite is the eastern honey bee Apis cerana Fabricius, 1793. However, in the beginning of the $20^{\text {th }}$ century, the Varroa mite encountered very favorable reproductive and developmental conditions on the honey bee (Apis mellifera $L$.) that lacks a genetic predisposition to suppress this parasite. The life cycle of the Varroa mite takes place exclusively on a bee brood. The mite deprives bees of nutrients by sucking hemolymph and often acts as a vector for viral bee diseases or transmits the parasite Nosema apis that causes diarrhea in the bees. The enormous breeding potential of the mite enables it to kill even a strong colony during one season. The number of parasites in the hive can triple in one month and colonies may therefore contain thousands of mites at the end of summer. This massive infestation dramatically shortens the life of bees. As parasitized bees usually perish in autumn and do not survive the winter, the colony dies (Rosenkranz et al. 2010).

Beekeepers have a variety of toxic chemicals at their disposal to exterminate mites. However, mites have already developed resistance to many such pesticides, which may furthermore contaminate the bee product. Moreover, some pesticides persist in the wax of the combs, which has led to a ban on synthetic liposoluble drugs in many countries. Remedies based on organic acids in unsuitable concentrations may harm the queen and the brood. The only highly effective alternative method to chemical treatment is a physical elimination of the Varroa mite by increasing the temperature in the hive. Varroa destructor is a strictly stenothermal parasite capable of reproduction in a narrow temperature range between 26 and $33^{\circ} \mathrm{C}$ (Rosenkranz et al. 2010; Pätzold \& Ritter 1989). Apis cerana defends itself against mites by heating the worker brood to a temperature above $35.5{ }^{\circ} \mathrm{C}$, at which the developmental stages of the mite are no longer capable of normal development. The drone brood of Apis cerana is heated only to $92.3{ }^{\circ} \mathrm{F}\left(33.5^{\circ} \mathrm{C}\right)$, which does not harm the mites (Erickson et al. 2000). The mites in Apis cerana are therefore enabled to parasitize primarily on drone brood. Some studies suggest that if the mite parasitizes on a worker brood, the per- 
centage of infertility in female mites is very close or equal to $100 \%$ (Zhou et. al. 2004; Rosenkranz and Engels, 1994). Other studies have shown that the optimum temperature for the development of mites lies between 32.5 and $33.4{ }^{\circ} \mathrm{C}\left(90.5-92.1{ }^{\circ} \mathrm{F}\right)$. The reproductive capability of female mites significantly decreases at temperatures above $36.5^{\circ} \mathrm{C}\left(98^{\circ} \mathrm{F}\right)$, and above $38^{\circ} \mathrm{C}\left(100.4^{\circ} \mathrm{F}\right)$ mites die without engaging in reproduction (Le Conte et al. 1990).

The aim of the submitted work is to test the efficiency of therapeutic heating in a thermosolar hive on the mortality of mites, and to evaluate effects of therapeutic heating on the bee brood, the adult bees and the stability of the bee work.

\section{Material and method}

The therapeutic equipment that was tested on its efficiency in exterminating the mites was Linhart's thermosolar hive (Fig. 1). It is a classic multiple-storey hive that is structurally adapted for the transformation of energy from sunlight into thermal energy. The brood chamber is heated by means of two heating systems that permit temperature regulation. The first system consists of a glass thermosolar ceiling that is activated by removal of the roof cover. After reaching a temperature of $47{ }^{\circ} \mathrm{C}$, a hive roof is mounted to prevent further heating. The ceiling includes two temperature sensors that are introduced into the wax of the middle brood comb prior to the treatment and enable control on interior temperature. The second heating system consists of glass thermosolar windows. These are exposed with the possibility of being covered in the case of elevated ambient temperatures. The dimensions of the frames are $39 \times 24 \mathrm{~cm}$, which represents the most common frame size used in the Czech Republic.

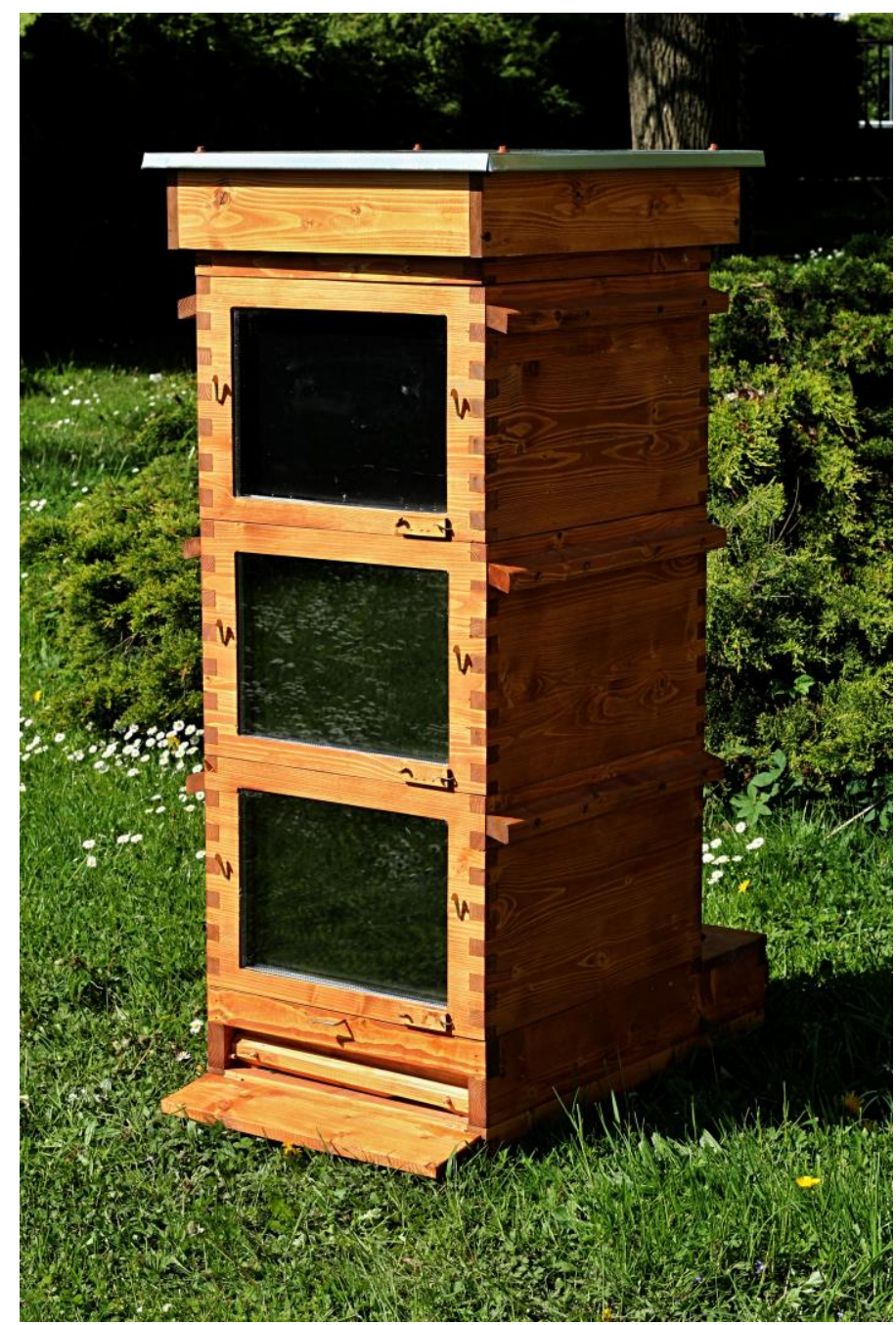

Fig 1: Thermosolar hive 
Five colonies in ordinary hives, heavily infested with mites, were selected at the beginning of the experiment on July 24, 2015. A high infestation rate was indicated by a natural fallout of two or more mites per day, as revealed by using a special floorboard. These five colonies served as donors of brood combs sufficiently infested by mites. Three sealed brood combs were removed from each of the five infested colonies. These consisted of two combs with a worker bee brood and one comb with a drone brood. Bees were swept off the combs and the combs were subsequently placed in the upper honey part of the thermosolar hive. Digital thermometer sensors were placed into the wax of these combs. One of the sensors was placed under an upper bar of the comb and another one in the lower bar. The combs were then left for one hour to be treaded by bees, allowing them to regulate humidity and care for the brood during the experiment.

At the beginning of the experimental heating cycle, at 8:00 a.m., the outside temperature in the shade was $20{ }^{\circ} \mathrm{C}\left(68^{\circ} \mathrm{F}\right)$. After the hive reached a temperature of $47^{\circ} \mathrm{C}\left(116.6^{\circ} \mathrm{F}\right)$ at the upper bar of the comb, at $11: 30$ a.m., the roof was mounted. The honeycombs were exposed to temperatures of $40-47^{\circ} \mathrm{C}\left(104-116.6^{\circ} \mathrm{F}\right)$ for a duration of 150 minutes (starting from the moment when the temperature reached $40{ }^{\circ} \mathrm{C}$ at the level of the lower sensor). After heating, the experimental combs were removed, placed into a bag of dense, solid mesh, and moved into a brood chamber in the ordinary hive from which they had originally been taken. After the entire brood had emerged on August 7, 2015, dead mites and dead bees that had accumulated on the bottom of the bags were counted. Fumigation was applied later on the same day to assess how many mites survived the therapeutic heating. This was achieved using a Varidol product known to kill phoretic mites with $95 \%$ efficiency. Dead mites were collected from the bottom of the bag two hours after fumigation. The efficiency of solar thermotherapy was defined as the ratio of the number of mites killed by thermotherapy to those killed chemically by fumigation. After fumigation, bee mortality was monitored until August 21, 2015. The colony was supplied with food and water during this period. Attention was also paid to possible developmental abnormalities that could have been caused by heating.

The effect on the bee work was studied during the heating of five colonies subjected to thermotherapy. Frames were exposed to temperatures of $40-47^{\circ} \mathrm{C}\left(104-116.6^{\circ} \mathrm{F}\right)$ for 150 minutes and subsequently removed and examined. It was determined whether visible deformation of the combs, such as sliding down of the work, had occurred. Both the brood combs and honey combs were inspected. After heating, ten honeycombs were removed from each hive and visually assessed with regard to any damage incurred. In order to increase the predictive value of the experiment both, virgin honeycombs and post-brood honeycombs were assessed.

\section{Results}

As no damage to either virgin or post-brood honeycombs was registered, thermotherapy is concluded not to have affected the stability of the bee work. Therapeutic heating did not adversely affect adult workers and queens either.

Thermotherapy was observed to be highly effective in exterminating mites on sealed brood (Fig. 2). While mite fallout after thermotherapy was considerable, it was only incidental following fumigation (Graph 1).

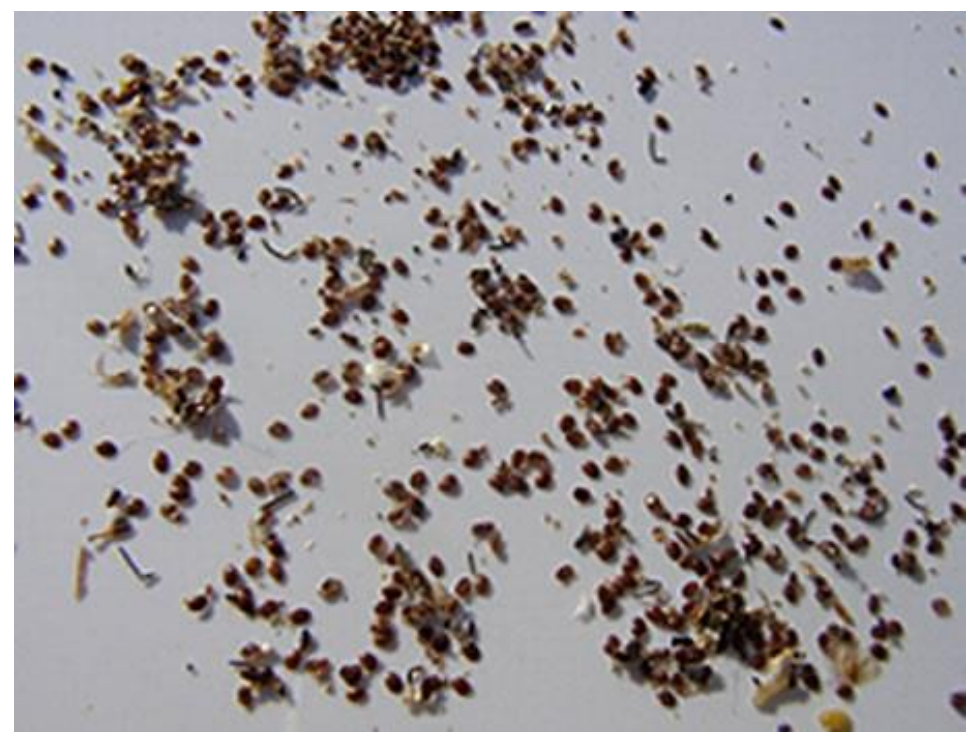

Fig 2: Sample fallout of mites from insulators 


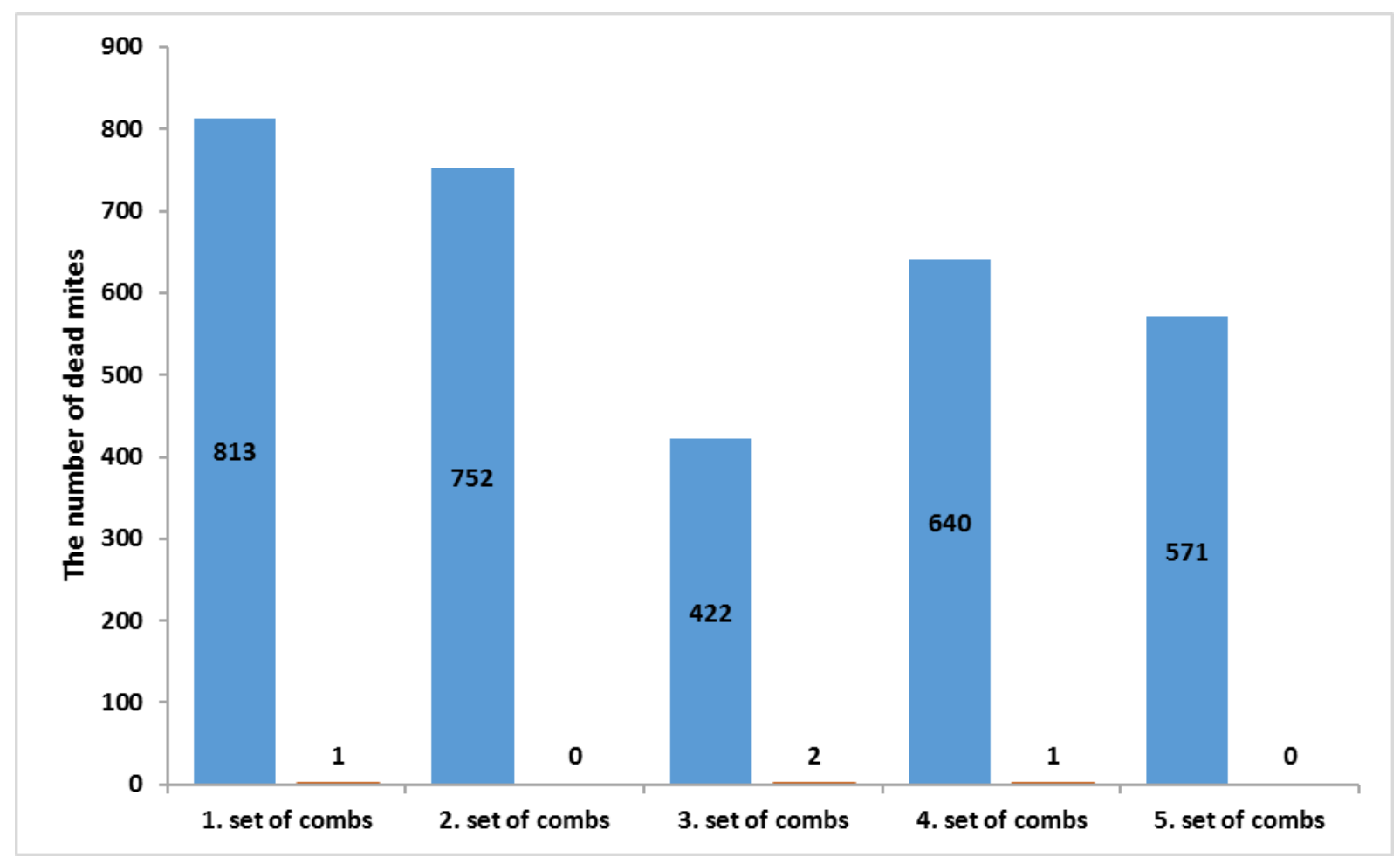

Graph 1: Fallout of Varroa destructor after the application of thermotherapy (blue) and fallout after fumigation of combs applied later on the same day (brown).

We cannot exclude the possibility that Varroa specimens recovered after chemical treatment had already been killed by thermotherapy. Dead mites may remain in the cells for several hours until workers carry them out of the cells after the emergence of young bees. It is also possible that these rare mites were indeed killed off by the chemical treatment (Table 1). Whether or not thermosolar treatment killed the entire mite population is not entirely certain, but is highly probable. Our results demonstrate that heating surely killed the vast majority of mites present. We may furthermore assume that possibly surviving mites were damaged. Thermotherapy can therefore be considered an adequate alternative to chemical treatment in exterminating the Varroa mite.

Table 1: Quantified efficiency of thermotherapy relative to fumigation in the extermination of Varroa mites

\begin{tabular}{|c|c|c|c|c|}
\hline & $\begin{array}{c}\text { The number of dead Varroa } \\
\text { after thermotherapy } \\
\text { (absolute numbers) }\end{array}$ & $\begin{array}{c}\text { The number of dead Varroa } \\
\text { after fumigation } \\
\text { (absolute numbers) }\end{array}$ & $\begin{array}{c}\text { The amount of dead Varroa } \\
\text { after thermotherapy } \\
\text { (in percentage of total) }\end{array}$ & $\begin{array}{c}\text { The amount of dead Varroa } \\
\text { after fumigation } \\
\text { (in percentage of total) }\end{array}$ \\
\hline $\begin{array}{c}\text { 1. set of } \\
\text { combs }\end{array}$ & 813 & 1 & 99.88 & 0.12 \\
\hline $\begin{array}{c}\text { 2. set of } \\
\text { combs }\end{array}$ & 752 & 0 & 100 & 0 \\
\hline $\begin{array}{c}\text { 3. set of } \\
\text { combs }\end{array}$ & 422 & 2 & 99.53 & 0.47 \\
\hline $\begin{array}{c}\text { 4. set of } \\
\text { combs }\end{array}$ & 640 & 1 & 99.84 & 0.16 \\
\hline $\begin{array}{c}\text { 5. set of } \\
\text { combs }\end{array}$ & 571 & 0 & 100 & 0 \\
\hline
\end{tabular}

During the monitoring period of 14 days following treatment, death among young bees was negligible (Table 2). In each isolator, no more than tens of individuals were observed. This is the standard mortality rate among young bees in colonies not exposed to any method 
of treatment and has no effect on the vitality of the colony as a whole. Careful examination of living and dead bees revealed no morphological abnormalities.

Table 2. The number of dead bees encountered in insulators (*)

\begin{tabular}{|c|c|c|c|c|c|}
\hline & 1. set of combs & 2. set of combs & 3. set of combs & 4. set of combs & 5. set of combs \\
\hline $\begin{array}{c}\text { The number of dead bees } \\
\text { in the insulator } \\
\text { (absolute numbers) }\end{array}$ & 12 & 25 & 21 & 31 & 14 \\
\hline $\begin{array}{c}\text { The number of dead bees } \\
\text { in the insulator } \\
\text { (in percentage of total)* }\end{array}$ & 0.08 & 0.17 & 0.15 & 0.22 & 0.1 \\
\hline
\end{tabular}

* One frame with worker bee brood that measures $15.35 \times 9.44$ inches $(39 \times 24 \mathrm{~cm})$ contains a total of 7488 brood cells. For the purpose of this experiment, we used frames brooded to $65 \%$ (35\% of the cells contained honey and pollen). A frame with the same dimensions accommodating drone brood contains a total of 4680 brood cells. Drone frames were brooded to $90 \%$. Each insulator housed two frames of worker bee comb and one frame of drone comb. Therefore, the mean number of bees hatched in each insulator was 13946.

Deaths of older bees and queens were not recorded. Because an open hive_entrance was maintained during treatment, bees could fly out of the hive ad libidum. Workers and queens could also move away from the heat source to a cool bottom board of the hive. Because bees can seek a suitable temperature during heating of the brood, we do not consider damage to adult individuals a theoretical possibility. No signs of damage to the brood or abnormalities in oviposition by the queens was registered, nor did the bee work experience damage. The melting point of wax is $60-62{ }^{\circ} \mathrm{C}\left(140-143.6^{\circ} \mathrm{F}\right)$ and this temperature was far from being reached during treatment. Wax loses its mechanical strength at temperatures exceeding $49{ }^{\circ} \mathrm{C}(120.2$ ${ }^{\circ} \mathrm{F}$ ), but since the highest temperature achieved during thermotherapy was $47{ }^{\circ} \mathrm{C}$ $\left(116.6^{\circ} \mathrm{F}\right)$, the structural integrity of the work remained ensured.

\section{Discussion}

The honey bee, unlike Apis cerana, is threatened by Varroa destructor because it heats worker sealed brood to temperatures below $35.5^{\circ} \mathrm{C}\left(96^{\circ} \mathrm{F}\right)$. Normal temperatures in the brood chambers of the honey bee range between $33.6-34.4^{\circ} \mathrm{C}\left(92,4-94{ }^{\circ} \mathrm{F}\right)$. Temperatures rarely rise above $35^{\circ} \mathrm{C}\left(95^{\circ} \mathrm{F}\right)$, and generally only just before swarming or during the construction of new combs. Temperatures below $35^{\circ} \mathrm{C}\left(95^{\circ} \mathrm{F}\right)$ provide ideal conditions for the reproduction of mites and allow them to parasitize even on a sealed brood of worker honey bees.

The biological mechanism underlying the damage experienced by Varroa destructor under the influence of elevated temperatures is not yet completely understood. One can assume that the increase in temperature affects the protein biosynthesis of enzymes involved in the metabolism of the parasite. Since proteins are species-typical, proteins of honey bees and their brood can endure higher temperatures than proteins of the mite.

Some researchers have used elevated temperatures to kill mites found in a sealed brood and reported no or minimal harm to the brood (Huang 2001; Rosenkranz 1987; Brødsgaard \& Hansen 1994). Experimental extermination of mites on adult bees was also found effective. This method is, however, technically and methodically more demanding because of the narrow temperature range in which mites are killed but adult bees are not yet damaged (Harbo 2000). Some authors exposed adult bees to high temperatures, $\left(40^{\circ} \mathrm{C}, 104{ }^{\circ} \mathrm{F}\right)$ over a longer period of time and found that an increased mortality occurred during exposure to such temperatures for more than 48 hours (Harbo 2000; Tabor \& Ambrose 2001). The elimination 
of mites in a sealed brood is a far simpler and safer method because temperatures above $40{ }^{\circ} \mathrm{C}$ $\left(104^{\circ} \mathrm{F}\right)$ have a short-term effect and do not adversely affect the colony.

The results achieved by our experiments largely correlate with the findings published at Bratislava International Conference on thermal elimination of mites on October 17, 2015. Authors Wolfgang Sommer (Austria) and Olga Cadosch (Switzerland) stated, based on their long-term research, that:

1. For a large group of colonies and over the course of several years, it was found that heating of the brood combs is an equally successful alternative to chemical treatment. Fifty colonies treated in this way thrived for three years without chemical treatment. Colonies treated with thermotherapy not only produced high-quality honey, but were also vital and capable of generating divides.

2. Bee brood can withstand higher temperatures than mites, and that heating kills the mites, but not bee larvae.

3. It is possible to effectively heat the sealed brood.

4. Mites do not survive at a temperature of $45{ }^{\circ} \mathrm{C}$, which represents a rise in the temperature of the brood nest by a mere $10{ }^{\circ} \mathrm{C}$ above normal.

5. Ideal temperatures for the development of the mite are below $35^{\circ} \mathrm{C}$, and that even the upper limit of the normal temperature range for the brood is not suitable for the parasites.

6. Even colonies completely cured in summer can be reinfested in late summer due to reinvasion.

The results presented at the referred conference were obtained by means of an electrical device named the Varroa Controller and involves a crucially different setup than the one used in our experiment. And yet, our conclusions are comparable with the presented data. This illustrates that solar thermotherapy is comparable in terms of effect and safety with thermotherapy founded on electric heating.

Thermotherapy has already been extensively tested in previous decades, but often by employing devices that were not very effective or inapplicable in practice because of their complexity and laboriousness. We therefore believe that Linhart's thermosolar hive may signify an important advance in the application of this treatment approach. Our experiment proves that thermotherapy is a highly promising method of eliminating mites without the need of chemical treatment.

Acknowledgements: The authors wish to acknowledge PhDr. Kamila Tozzi and Dennis F.A.E. Voeten for improving the English text.

\section{References}

Anderson D.L. \& Trueman J.W.H. (2000): Varroa jacobsoni (Acari: Varroidae) is more than one species. Experimental and Applied Acarology 24: 165-189.

Brødsgaard C.J. \& Hansen H. (1994): An example of integrated biotechnical and soft chemical control of varroa in a Danish apiary. In: Mathes on A. (ed.): New Perspectives on Varroa, pp. 101-105.

Erickson E.H., Page R.E. \& Hanna A.A. (2000): Proceedings of the 2nd International Conference on Africanized Honey Bees and Bee Mites, Tucson.

Harbo J.R. (2000): Heating adult honey bees to remove Varroa jacobsoni. - Journal of Apicultural Research 39(3-4): 181-183.

Huang Z. (2001): Mite zapper - a new and effective method for Varroa mite control. - American Bee Journal 141(10): 730-732.

Le Conte Y., Arnold G. \& Desenfant P. (1990): Influence of brood temperature and hygrometry variations on the development of the honey bee ectoparasite Varroa jacobsoni (Mesostigmata: Varroidae). - Environmental Entomology 19(6): 1780-1785.

Pätzold S. \& Ritter W. (1989): Studies on the behaviour of the honey-bee mite Varroa jacobsoni in a temperature gradient. - Journal of Applied Entomology 107: 46-51. 
Rosenkranz P. (1987): Temperature treatment of sealed worker brood as a method of controlling Varroatosis. - Apidologie 18(4): 385-388.

Rosenkranz P., Aumeier P. \& Ziegelmann B. (2010): Biology and control of Varroa destructor. - Journal of Invertebrate Pathology 103: 96-119.

Rosenkranz P. \& Engels W. (1994): Infertility of Varroa jacobsoni females after invasion into Apis mellifera worker brood as a tolerance factor against varroatosis. - Apidologie 25(4): 402-411.

Tabor K.L. \& Ambrose J.T. (2001): The use of heat treatment for control of the honey bee mite, Varroa destructor. - American Bee Journal 141(10): 733-736.

Zhou T., Anderson D., Huang Z., Huang S., Yao J., Ken T. \& Zhang Q. (2004): Identification of Varroa mites (Acari: Varroidae) infesting Apis cerana and Apis mellifera in China. - Apidologie 35: 645654.

Authors' addresses: Vítězslav Bičík, Department of Zoology, Faculty of Science, Palacký University in Olomouc, Czech Republic.

E-mail: bicikv@seznam.cz

Jiří Vagera, Department of Biology, Faculty of Education, Palacký University in Olomouc, Czech Republic.

E-mail: jiri.vagera@ seznam.cz

Hana Sádovská, Department of Agroecosystems, Faculty of Agriculture, University of South Bohemia in České Budějovice, Czech Republic.

E-mail: handulkacr@ seznam.cz 